\title{
Revisiting Translation Strategies and Techniques
}

\author{
Ngoran Constantine Tardzenyuy \\ Advanced School of Translators and Interpreters, University of Buea, Cameroon
}

Received: 17-08-2016

doi:10.7575/aiac.ijclts.v.4n.4p.48
Accepted: 19-09-2016

Published: 31-10-2016

URL: http://dx.doi.org/10.7575/aiac.ijclts.v.4n.4p.48

\begin{abstract}
Many translation researchers, scholars and students or trainees have the tendency to use the terms 'translation strategy', translation technique' 'translation method' and 'translation procedure' invariably, and sometimes with varying shades of meaning This paper attempts to define, distinguish and clarify these terms in a bid to give the study of translation the scientific basis it deserves, given that scientific terminology is bound to be clear and unequivocal. Employing the qualitative research method and secondary or documentary sources, the paper provides elaborate explanations of the terms using sourced and invented examples. The paper concludes that the term 'translation strategy' should be used strictly to refer to a global or general decision a translator takes before engaging in the translation of any text. Such a general decision could concern the issue of whether the translation would be literal, foreignized or source-text oriented; or whether it would be free, oblique, domesticated or target-text-oriented. On the other hand, the paper conclusively contends that all the other terms, that is to say, 'translation technique, 'translation procedure' and 'translation method' should be used to refer to tools or operational measures deployed by the translator in the course of actual translation. In other words, they should be used as mechanisms for effecting general or globalizing translation strategies.
\end{abstract}

Keywords: Translation, Strategy, Translation, Technique, Foreignization, Domestication.

\section{Introduction}

Generally speaking, there are two main translation strategies, which have over the year been given various names. However, the common denominator in this variety of names is that on the one hand, there is the translation strategy that advocates literality and faithfulness to the original and on the other that which advocates free, natural, transparent and message for message rendering. Current terminology in Translation Studies use ' foreignization' and 'domestication' respectively for a translation strategy which is source-text oriented, word for word; structure for structure and literal, and for that which is target text-oriented, free, natural, transparent and message for message. In a strict sense; a translation strategy is a pre-translation decision that is taken by the translator before engaging in the actual translation, while a translation technique is a practical method by which a translation strategy is operationalized. Nonetheless the two terms are often used invariably to main method or procedure of carrying out a translation exercise. In fact, many translation researchers, scholars and students or trainees have the tendency to use the terms ' translation strategy', 'translation technique', 'translation method' and 'translation procedure' invariably, and sometimes with varying shades of meaning.

This paper attempts to define, distinguish and clarify these terms in a bid to give the study of translation the scientific basis it deserves, given that scientific terminology is bound to be clear and unequivocal. Employing the qualitative research method and secondary or documentary sources, this paper provides elaborate explanations of the terms using sourced and invented examples.

\section{Definitions and Discussion}

\subsection{Foreignization (literal translation, source-text-oriented translation)}

This is a translation strategy in which there is 'close adherence to the source text structure and syntax (Munday, 2001: 147). In other words, it is source-text-oriented translation, which gives priority to adequacy, at the expense of appropriacy and acceptability. According to Venuti (cited by Munday, 2001:147) foreignization is a translation strategy in which there is 'close adherence to the source text structure and syntax'. In other words, it is source-text-oriented translation, which gives priority to adequacy. It is more or less literal translation. In foreignization, the reader is taken closer to the foreign language author, the foreign language itself as well as the foreign culture. In a foreignizing style of writing, no attempt is made whatsoever to simplify the language and the notions in the text in order to ease understanding for the non-native reader. Rather, the foreign reader is allowed to go the extra mile in a bid to understand what is written in a language that is not his or her own.

It is more or less literal translation. The techniques often used to effect his strategy include literal translation, wordfor-word translation, borrowing and calque.

\subsection{Domestication (Free, oblique, target-text-oriented translation)}

According to Venuti, (1995, cited by Munday, 2001:.146), domestication is a translation strategy which 'entails translating in a transparent, fluent, invisible style' in order to minimize the foreignness of the target text'. It is target- 
text-oriented translation with focus on the respect of target text norms. In Descriptive Translation Studies (Toury, 1995) terminology, it is appropriate and acceptable translation.

Translation techniques used to operationalize this strategy include expansion, explicitation, transposition, modulation, reformulation, omission, cultural equivalence, dynamic equivalence, synonymy, local adaptation and global adaptation

\subsection{Translation Technique}

A translation technique is an operational mechanism put in place by the translator in the course of actual translation. In other words, it is a micro method for operationalizing a general or globalizing translation strategy.

2.3.1 Translation techniques used for the operationalization of the Translation Strategy of Foreignization

\subsubsection{Lterral Translation}

This is a word for word or structure by structure rendition from the source to the target text.

Below is an example of literal translation. Examples of formal correspondence given later in this write-up are typical examples of the literal translation technique.

SLT (Source Language Text): Meka était un grand favori dans la course au Paradis, l'un des plus rares mortels qui ne feraient qu'une apparition au Purgatoire.

TLT (Target Language Text): Meka was the great favourite in the paradise stakes, one of those rare mortals who would have no more than a mere appearance to put in at purgatory

\subsubsection{Borrowing}

Borrowing is a translation technique in which 'the SL word is transferred directly to the TL' (Munday 2001:56). It can otherwise be simply defined as the taking of words from one language into another. This usage is of course done in a naturalized form, that is, in such a way as to conform to the rules of grammar or punctuation of the target language. Suh (2005:122) defines borrowing as the transfer of source text lexemes or lexeme combination into the target language, normally without formal or semantic modification. Borrowing can mainly be used as a way to preserve the local colour of the word, or be used out of fear of losing some of the semantic and cultural aspects of the word if it is translated. It is worth mentioning that it is difficult to see a language that is completely independent of others In fact, all languages borrow from others. In the case of bible translation, a word like Pharisee has been borrowed from the original Hebrew through Aramaic, Greek, Latin, English, and French and down to African and Cameroonian languages. . Dictionaries have only succeeded to describe and explain their meanings but they have never been translated as such. It is often used to cover cultural aspects, expressed in the source text, which are absent in the target language. It is sometimes employed to add local colour. A word that is borrowed is technically described as a loanword or borrowing. It can also be called a loan translation. Sometimes borrowed words or terms are modified phonologically and orthographically.

In Bible English-Lamnso translation, borrowing is abundantly used in the Lamnso rendering of the names of people and places, which are borrowed and modified phonologically and orthographically in the target language. In this regard, English names such as Joseph, Philip, Emmanuel, Moses, Thaddeus, Alphaeus, Thomas and James respectively become Joosev, Filiv, Emmanuwer, Mooser, Taadiyor, Afiyur, Tomar and Jeem in Lamnso. Similarly, names of places in English such as Bethlehem, Nazareth, Egypt and Capernaum respectively become Betilehem, Naasarer, Ejiv and Kapenahuum. Other cases of borrowing include Satan and Farasii. The following is an example of borrowing as translation technique It is an excerpt from the English translation ( by Peter Green,) of Mongo Beti’s (1964) Mission terminée.

SLT: Mon imagination tournait à plein regime: le recalé au baccalauréat se muait en condottière ou carbonaro ou je ne sais plus quel conquistador... (p.29).

TLT: My imagination was running away with me. The ploughed student was transformed into a brigand chief, a pirate, a true Conquistador. (p.16).

In the example above the word' conquistador' is borrowed from French, which is the source language, and used in English, the target language.

It worth noting here that borrowing is not peculiar to translation but is rather a common phenomenon in all languages. All languages borrow from other languages. Generally speaking, languages of wider diffusion borrow less from those of lesser diffusion and vice versa, that is language $\mathrm{s}$ of lesser diffusion have a tendency to borrow more from those of wider diffusion. In other words, strong, well-established and widely spoken and written languages borrow less from weak, less-established and sparsely spoken and written languages. However, in the case of world languages like English and French, borrowing depends so much on the origin of innovations and discoveries.

According to Krysstal (20166), the English language has borrowed an impressive number of words from French. Here are some of those words;

$\begin{array}{llllll}\text { a la carte } & \text { laissez faire } & \text { Reservoir } & \text { Arson } & \text { Margarine } & \text { Revenue } \\ \text { Abattoir } & \text { Lieutenant } & \text { Resign } & \text { Attaché } & \text { Marinade } & \text { Ricochet } \\ \text { Ambulance } & \text { Macabre } & \text { Restaurant } & \text { Ballet } & \text { Maroon } & \text { Rifle }\end{array}$




\begin{tabular}{|c|c|c|c|c|c|}
\hline Arson & Margarine & Revenue & Bayonet & Mauve & Roast \\
\hline Attaché & Marinade & Ricochet & Biscuit & Mayonnaise & Roulette \\
\hline Ballet & Maroon & Rifle & bon vivant & Memoir & Rout \\
\hline Bayonet & Mauve & Roast & Bribe & Menu & Route \\
\hline Biscuit & Mayonnaise & Roulette & Cabaret & Mortgage & Routine \\
\hline bon vivant & Memoir & Rout & Cache & Mutiny & Séance \\
\hline Bribe & Menu & Route & Camouflage & Nasal & Sabotage \\
\hline Cabaret & Mortgage & Routine & carte blanche & Niece & Sachet \\
\hline Cache & Mutiny & Séance & Chauffeur & Nomad & Salvage \\
\hline Camouflage & Nasal & Sabotage & Corduroy & nouveau riche & Satchel \\
\hline carte blanche & Niece & Sachet & coup d'etat & Omelette & Sauce \\
\hline Chauffeur & Nomad & Salvage & Coupon & Panache & Saucer \\
\hline Corduroy & nouveau riche & Satchel & Courier & par excellence & Sauté \\
\hline coup d'etat & Omelette & Sauce & Crayon & Parachute & Saveloy \\
\hline Coupon & Panache & Saucer & Crochet & Picnic & savoir faire \\
\hline Courier & par excellence & Sauté & Croquet & Pioneer & Sirloin \\
\hline Crayon & Parachute & Saveloy & Debris & Plaice & Somersault \\
\hline Crochet & Picnic & savoir faire & Denim & Plaque & Soufflé \\
\hline Croquet & Pioneer & Sirloin & Dentist & Portrait & Soup \\
\hline Debris & Plaice & Somersault & Detour & Promenade & Souvenir \\
\hline Denim & Plaque & Soufflé & Diplomat & Publicity & Spiral \\
\hline Dentist & Portrait & Soup & Dossier & Queue & Splendid \\
\hline Detour & Promenade & Souvenir & en masse & Role & Sport \\
\hline Diplomat & Publicity & Spiral & en route & Raffle & Suede \\
\hline Dossier & Queue & Splendid & Entrepreneur & raison d'Etre & Syndicate \\
\hline en masse & Role & Sport & Envoy & Rapport & Tampon \\
\hline en route & Raffle & Suede & Espionage & Ratchet & Tangerine \\
\hline Entrepreneur & raison d'Etre & Syndicate & Etiquette & Rectangle & Tapestry \\
\hline Envoy & Rapport & Tampon & fait accompli & Regal & Torture \\
\hline Espionage & Ratchet & Tangerine & faux pas & Regime & Traffic \\
\hline Etiquette & Rectangle & Tapestry & Gaffe & Relay & Tranquil \\
\hline fait accompli & Regal & Torture & Gourmet & Renaissance & Trophy \\
\hline faux pas & Regime & Traffic & Grape & Rendezvous & Umpire \\
\hline Gaffe & Relay & Tranquil & hors d'oeuvre & Reprimand & Unique \\
\hline Gourmet & Renaissance & a la carte & laissez faire & Reservoir & Velocity \\
\hline Grape & Rendezvous & Abattoir & Lieutenant & Resign & Version \\
\hline \multirow[t]{4}{*}{ hors d'oeuvre } & Reprimand & Ambulance & Macabre & Restaurant & Visa \\
\hline & & & & & Wardrobe \\
\hline & & & & & Zest \\
\hline & & & & & Zigzag \\
\hline
\end{tabular}

Similarly, the French language equally borrows from English or rather uses a good number of English words. The following are some of the English words often used in the French language either as a way to go with the mode of the time, which appears to be dictated by the English culture and more specifically by American fashion, which happens to be couched in the English language: 


\begin{tabular}{|c|c|c|}
\hline \multicolumn{3}{|c|}{ Here are examples of English words used in the French language (FrenchCrazy): } \\
\hline Okay / OK or K & Briefing & Boguer \\
\hline Happy Hour & Debrief & Hamburger \\
\hline Brainstorming & ASAP & Steak \\
\hline Week-end & Footing & Hot dog \\
\hline Stop / Stopper & Jogging & Chili con carne, etc... \\
\hline Football & THUG & Starbucks \\
\hline Basketball & GANGSTA & Coca (Cola) \\
\hline Rugby & $\mathrm{ma} / \mathrm{ta}$ Life & McDo (for McDonalds) \\
\hline Brunch & Interview & Apple \\
\hline Smoking & Un Meeting & iPhone \\
\hline Okay / OK or K & Replay & Google \\
\hline Happy Hour & en Streaming & Wi-Fi, etc... \\
\hline Brainstorming & en live & Boguer \\
\hline Week-end & Kidnappeur & Patch \\
\hline Stop / Stopper & Kidnapper & Hacker \\
\hline Sweat & Marketing & Greetings \\
\hline String & Mail & Dress-code \\
\hline Slip & Email & Cookie \\
\hline Pull & Chat & Muffin \\
\hline T-shirt & Un Meeting & Brownie \\
\hline Job & $\mathrm{Blog}$ & Hamburger \\
\hline Has Been & Boguer & \\
\hline Parking & Bug & \\
\hline LOL & Boguer & \\
\hline SWAG & Patch & \\
\hline Sweat & Hacker & \\
\hline THUG & Greetings & \\
\hline GANGSTA & Dress-code & \\
\hline ma/ta Life & Cookie & \\
\hline Interview & Muffin & \\
\hline Interviewer & Brownie & \\
\hline
\end{tabular}

\subsubsection{Calque}

This is also known as the direct translation technique. A calque or a loan translation is a phrase borrowed from another language and translated literally (word for word) to describe a concept in the exact words of the source, but codified in the target language as its norms prescribe.

The meaning of some calques can be rather obscure for most people, especially when it relates to specific vocations or domains such as science and law. For example, Solution de compromise is a Spanish legal term taken from the English compromise solution and although Spanish attorneys understand it, the meaning is not readily understood by the layman.

An unsuccessful calque can be extremely unnatural, and can cause unwanted humour, often interpreted as a lack of expertise off the translator in the target language. A good excuse for using calque in translation would be that the word or expression was conceived in the source language to refer to and describe a particular notion or concept and that saying it otherwise would betray the originally intended meaning. When a target language has lacks terms, translators borrow those terms from the source language, thereby enriching the target language.

Thanks to exchange of calques and loanwords between languages, and to their importation from other languages, there are few concepts that are untranslatable among modern languages. In other words, due to the impossibility to translate certain concepts, calques and loanwords are quick solutions to such blockages.

The following is a typical example of a calque where an Ijaw proverb is translated literally into English and then into French: 
'If you roast a bird of the air before a fowl, the fowl's head aches' (English rendering from Ijaw, an East Nigerian language)

«Si tu fais rôtir un oiseau de l'air devant une volaille, la volaille a la migraine» (French rendering from the English translation)

2.3.2 Translation Techniques for the Operationalization of the Translation Strategy of Domestication

\subsubsection{Transposition}

This is a translation technique where there is a change in part of speech in the target language. A verb, for instance, may become a noun, and a noun may become a pronoun. Here are some examples of transposition drawn from Le vieux nègre et la médaille and its English version The Old Man and the Medal' (Oyono, 1956, 1969) (the parts of speech indicating transposition appear in italics):

SLT: Ils prièrent d'une voix monotone et chantante.

TLT: They said their prayers_in a monotonous singsong.

SLT : Apporte-moi à manger

TLT: Bring me food

SLT: La case était déjà animée. Tous ceux qui se rendaient au travail au quartier blanc venaient là, chez Mami Titi, prendre leur viatique pour la journée.

TLT: The hut was already alive. Everyone who went to work in the European quarter came there to Mammy Titi's to fortify_themselves for the day.

SLT: Ils se mesurèrent du regard et le jeune home, un petit sourire en coin, s'en fuit en époussétant le fond de son pagne.

TLT: They looked at each other up and down. Then the young man smiling a little at the corner of his mouth went out, smacking the dust from the seal of his cloth as he went.

SLT: Ses hommes désespéraient de mettre la main sur quelque vendeur clandestin.

TLT: His men had been trying desperately_to lay their hands on whoever was selling the stuff in secret.

SLT: Il avait eu la grâce insigne d'être la propriétaire d'une terre qui, un beau matin, plut au bon Dieu.

TLT: He had had the special grace to be the owner of a piece of land, which one fine morning, had proved pleasing to the eyes of the Lord.

SLT: Comment pourait-on aller contre la volonté de celui qui donne?

TLT: How could he go against the will of the Lord_who giveth.

SLT: Il suivit, enthousiaste l'édification du quartier du Seigneur sur la terre de ses encêtres

TLT: Full of enthusiasm, he followed the raising of the house of the Lord on the land of his forefathers.

SLT: Quand, la veille de l'inauguration par l'évêque on l'invita à choisir sa place dans l'église.

TLT: On the eve before the church was inaugurated by the Bishop, he was asked to choose his place in the church.

SLT: Ignace Obebé entra. Bâti en force, il inspirait la crainte avec son coup de buffle et sa tête, très mobile.

TLT: Ignatius Obebe came in. He was strongly built and frightening with his buffalo neck and shifty eyes at the top of his face.

\subsubsection{Modulaition}

Modulation is a translation technique in which there is a change in semantics and point of view.

Modulation is both communicative and pragmatic translation. It could also be likened to paraphrase. Paraphrase, proposed and recommended by Dryden (1680) in the preface to his translation of Ovid's Epistles, is:

Translation with latitude, where the author is kept in view

by the translator so as never to be lost, but his words are not

so strictly followed as his sense'(Munday 2001:25)

Below are some examples of modulation from Le vieux nègre et la médaille and its English version The Old Man and the Meda' (Oyono, 1956, 1969) (the parts of speech indicating modulation appear in italics):.

SLT: Le vieux nègre'

TLT: The old man.

SLT:_Meka était en avance sur le bonjour du Seigneur.

TLT: Meka was already awake when the first ray of sunlight...

SLT: Il en voulait à sa femme qui continuait à ronfler

TLT: He felt irritated that his wife was still snoring 
SLT: Il paracheva son élégance en glissant la jugulaire sous le menton

TLT: He then gave the finishing touch to his attire by slipping the strap underneath his chin.

SLT: Tu es très bien, dit sa femme, on dirait un Pasteur americain

'TLT: You look very nice,' said his wife. 'Like an American missionary'

SLT: Apporte-moi à manger dit-il $^{2}$

TLT: Bring me food,' he said

SLT: Creve des nègres

TLT : Blacks' crave

SLT: Chez Mami Titi qui habitait le quartier indigène, c'était déjà la ville

TLT: Madam Titi lived in the African location and once you reached her place you were already in town

SLT: 'Comme des élastiques, elles revenaient'

'TLT: They sprang back'

SLT: C'est la même chose.

TLT: -What's the difference?

SLT: Toi, au moins, tu dis ce que tu penses, dit Meka

'TLT: At last you are frank about it', said Meka

SLT:C'est imprudent, ce que je vais faire là, dit Meka en protestant du chef.

TLT: 'It's very foolish what I am going there for', said Meka, shaking his head in protest.

SLT : A Doum on savait où conduisaient les convocations officielles.

TLT: At Doum, it was known what an official summons meant.

\subsubsection{Explicitation}

Explicitation can be considered a process of introducing something in the target language which is present only implicitly in the source language, but which can be derived from the context. .Seguinot (1988:106) includes issues like focus, emphasis and lexical choice in her view of explicitation when she says explicitation takes place not only when something is in the translation which was not expressed in the original, but also in cases where something which was implied or understood through presupposition in the source text is overtly expressed in the translation through focus, emphasis or lexical choice.

According to Vinay and Darbelnet (1995: 55), explicitation aims at expressing a contextual or situational element, which is unexpressed in the source language, thus introducing gains in the message. The tendency to make information clearer and easier to understand is inherent in every communication context. Here an example of explicitation:

SLT: Il a eu des rapports intimes avec sa charmante Épouse.

TLT: He had sexual intercourse with his charming wife

\subsubsection{Expansion}

This is a translation technique whereby the translator uses more words in the target text to convey the message in the source text. This is usually consequent on the systemic and cultural differences between languages. Generally speaking, the wider the distance or difference between two languages, the more the need for expansion in translating into or from each of them. Very often, expansion results from the desire to explain something that is not clearly expressed in the source language or to clear some ambiguity. .

Below are some examples of expansion:

SLT:-Il paracheva son élegance (4 words)

TLT: He then gave the finishing touch to his attire ( 9 words)

SLT : Chez Mami Titi qui habitait le quartier indigène, c'était déjà la ville (12 words)

TLT: Madam Titi lived in the African location and once you reached her place you were already in town (18 words)

SLT:-Meka avait pris les raccourcis, ces chemins sinueux, aux alentours des petites villes coloniales (14 words)

TLT: Meka had been taking short cuts down the winding paths, just visible in the grass, that always run through the stunted bush around colonial towns. (26 words)

SLT: Nous acceptors (2 words).

TLT: We accept your greetings' (4 words)

SLT: Ils se mesurèrent de regard et le jeune homme, un petit sourire en coin, s'en fuit en époussetant le fond de son pagne (24 words).

TLT: They looked at each other up and down. Then the young man smiling a little at the corner of his mouth went out, smacking the dust from the seal of his cloth as he went. (35 words). 
Newmark (1988:82) describes cultural equivalence as a translation procedure where a SL cultural word is translated by a TL cultural word. One of the debates on translations has always revolved around the question of whether, and to what degree the translation should reflect the syntax or form of the original language. However, translators agree that the translation should faithfully reflect the message of the original, but all are not agreed on whether the translation should adhere closely to the grammatical forms of the original language or lay emphasis just on the meaning.

There are however two basic orientations to this concept: formal and dynamic equivalence. The orientations are associated with Eugene Nida (1966) and were originally coined to describe ways of translating the Bible (even if the two approaches can be applicable to any translate.

\subsection{Formal Equivalence}

Formal equivalence focuses attention on the message itself, in both form and content. Here, the translator is concerned with such correspondences as word for word, sentence for sentence, and concept for concept. In other words, there is rigid adherence to the form of the original language.

Perceived from the formal orientation, there is concern that the message in the receptor language should match as closely as possible the different elements in the source language. This approach gives preference to literal fidelity

This means for example, that the message in the receptor culture is constantly compared with the message in the source culture to determine standards of accuracy and correctness. In simpler words, formal equivalence means choosing an expression that has one-to-one matching forms in the target language, regardless of whether the meaning is the same. Here are some examples of formal correspondence:

SLT: La bouche qui a tété n'oublie pas la saveur du lait.

TLT: The mouth that has sucked never forgets the taste of milk

SLT: Il a promis beaucoup de choses pour nous

TLT: He has promised a lot of things for us.

SLT: Nous avons mangé deux plats de nourriture ce matin.

TLT: We have eaten two plates of food this morning.

SLT: Les murs ont des Oreilles

TLT: The walls have ears.

SLT: Toutes les routes mènent à Rome.

TLT: All the roads lead to Rome.

\subsection{Dynamic Equivalence}

Dynamic equivalence advocates free translation. Nida and Taber $(1969 ; 12)$ assert that 'translating consists in reproducing in the receptor language the closest natural equivalent of the source language message, first in terms of meaning and secondly in terms of style'. This definition clearly indicates that they are not for formal equivalence. In short, dynamic equivalence simply means choosing words; expressions and a structure that will yield a message in the target text that is functionally equivalent to that in the source text.

Below are some proverbs in French and their English equivalents, which show dynamic equivalence:

SLT: La prudence est mère de sureté

TLT: Discretion is the better part of valour.

SLT: C'est en forgeant qu'on devient forgeron.

TLT: Practice makes perfect.

SLT: Chat échaude craint l'eau froide.

TLT: Once beaten twice shy.

SLT: Il y a plus de lumière en deux tètes qu'en une.

TLT: Two heads are better than one

SLT: La calque sent toujours le hareng

TLT: What is bred in the bone will come out in the flesh

\subsubsection{Adaptation}

Adaptation involves 'changing the cultural reference when a situation in the source culture does not exist in the target culture' (Munday 2001:59).

It should be noted here that when adaptation is extended to whole texts, it becomes a moot point where some translators have a tendency to argue that it ceases being translation.

Vinay and Darbelnet (1995: 56) define adaptation as 'a process which can be used whenever the context referred to in the original text does not exist in the culture of the target text, thereby necessitating some form of re-creation. 
This widely adopted definition views adaptation as a procedure employed to achieve an equivalence of situations whenever cultural mismatches are encountered. The decision to resort to adaptation may be prompted by issues like cross-code breakdown, situational inadequacy, genre switching, or disruption of the communication process (emergence of a new epoch). Judging from all the modes, conditions and restrictions that surround the notion of adaptation, two types can be distinguished;

\subsection{Local Adaptation}

Local adaptation involves picking part of a source text and 'adapting' them to the target text with strict respect to the norms and expectations of the target language and audience.

As a local procedure, adaptation may be applied to isolated parts of the text in order to deal with specific differences between the language and culture of the source text and that of the target text. As a result, the target text will not be strongly affected or transformed. The use of adaptation as a technique will have a limited effect on the text as a whole, provided the overall coherence of the source text is preserved. A typical example of local adaptation can be seen in the French rendering of the English proverb 'Rome was not built in a day' as 'Paris ne s'est pas faite en un jour, where 'Rome' becomes 'Paris'.

\subsection{Global Adaptation}

Global adaptation involves 'adapting' a whole text to suit the context and expectations of the target audience. According to Farghal $(1993 ; 257)$, adaptation as a global procedure may be applied to the text as a whole.

The decision to carry out a global adaptation may be taken by the translator himself or herself or may be imposed by external forces like the publisher's editorial policy. In either case, global adaptation constitutes a general strategy geared at reconstructing the purpose, function or impact of the original text. The intervention of the translator is systematic and he or she may sacrifice formal elements and even semantic meaning to reproduce the function of the original; Fonlon's (1972) English rendition of the second verse of the Cameroon National Anthem is a typical example of global adaptation as a translation technique:

SLT: Tu es la tombe où dorment nos pères,

Le jardin que nos aïeux ont cultivé.

Nous travaillons pour te rendre prospère.

Un beau jour enfin nous serons arrivés

De l'Afrique sois fidèle enfant,

Et progresse toujours en paix,

Espérant que tes jeunes enfants,

T'aimeront sans bornes à jamais.

TLT: From Shari, from where the Moungo meanders,

From along the banks of lowly Boumba stream,

Muster thy sons in union close around thee,

Mighty as the Buea Mountain be their team.

Instil in them the love of gentle ways,

Regret for errors of the past,

Foster for mother Africa a loyalty,

That true shall remain to the last.

\subsubsection{Reformulation}

This has to do with restructuring source text phrases, clauses, sentences and paragraphs, so that they are different in the target text.

SLT: Les jeunes filles ont été « échangées contre quatre prisonniers de Boko Haram ce matin », dans la région de Banki, a indiqué une source locale.

TLT: A local source indicated that the girls were liberated this morning in exchange for four Boko Haram prisoners in the region of Banki.

SLT: Les quatre combattants de Boko Haram sont arrivés à Banki depuis Maiduguri dans un hélicoptère de l'armée, et ont été conduits à Kumshedans des véhicules du CICR [Comité international de la Croix- Rouge] », a indiqué cette source proche du dossier.

TLT: This well informed source indicated that the four Boko Haram fighters were flown in an army helicopter to Banki from where they were driven in vehicles of the International Committee of the Red Cross (ICRC). 


\subsubsection{Synonymy}

This is a translation technique whereby the translator selects the closest synonym of the source language term to translate the term into the target language. This is often used when the translator cannot readily find an appropriate term in the target language to render a particular term found in the source language.

\subsubsection{Omission}

This is a translation technique whereby the translator omits a problematic culture-specific item completely. Suh (2005; 130) affirms that such a decision could simply be an act of desperation on the part of the translator who is unable to interpret the original. As a matter of fact, this translation technique should be avoided as much as possible because it often leads to leaving out meaning or part of it. On this score, it is needless to give examples of what is il-advised.

\section{Conclusion}

This study has moderately attempted to x-ray the various definitions and applications that have throughout the years been given the crucial terms 'translation strategy' and translation technique'.Given the central position these two terms occupy in translation research, pedagogy and practice; the study has all along tried to propose clear and definite definitions' and applications to the two terms so as to further consolidate the position of Translation Studies as a science of Applied Linguistics that employs clear and definite methods as well as unequivocal terminology. In a nutshell, the study proposes that the term 'translation strategy' should be used strictly to refer to a global or general decision a translator takes before engaging in the translation of any text. Such a general decision could concern the issue of whether the translation would be literal, foreignized or source-text -oriented; or whether it would be free, oblique, domesticated or target-text-oriented. On the other hand, the paper conclusively contends that all the other terms, that is to say 'translation technique, 'translation procedure' and 'translation method' should be used to refer to tools or operational measures used by the translator in the course of actual translation. In other words, they should be used as mechanisms for operationalizing general or globalizing translation strategies.

\section{References}

Brislin, R.W. (ed.) (1976). Translation, Applications and Research. New York: Gardner Press Inc.

Catford, J. (1965). A Linguistic Theory of Translation: An Essay in Applied

Krysstal (2016) .Borrowed Words (Frankish) Borrowed Words (Gaelic).Retrieved from http://www.krysstal.com

Farghal, M. (1993), 'Managing in Translation: A Theoretical Model', Meta, Vol.38 No.2 pp 257-267.

Fonlon, B. (1972).The English Version of the Cameroon National Anthem

French, C. (2015). Words French Steals from English. Retrieved from http://frenchcrazy.com/wp.content

Munday, J., (2001). Translation Studies: Theories and Applications. London Routledge.

Newmark, P. (1988). Approaches to Translation. Maryland: Prentice Hall International.

Nida E A (1966), Principles of Translation as Exemplified in Bible Translating, Oxford, Oxford University Press.

Nida, E.A. and Taber, C.R. (1969). repr. 1982. The Theory and Practice of Translation. Leiden:Brill.39

Oyono, F., (1956). Le vieux nègre et la médaille. Paris: Julliard. (Source of corpus)

Oyono, F., (1967). The Old Man and the Medal, (John Reed, Trans.). Oxford: Heinemann International Publishers.

Suh, J. (2005), 'A study of Translation Strategies in Guillaume Oyono Mbia's Plays' PhD thesis submitted to the University of South Africa.

Toury, G. (1995). 'The nature and role of norms in translation'. Translation Studies and Beyond. AmsterdamPhiladelphia: John Benjamins.

Toury, G., (1995). Descriptive Translation Studies and Beyond. Amsterdam: John Benjamins Publishing Matters.

Vinay, J. \& Darbelnet, J. (1958/1995). Stylistique comparée du français et de l'anglais : Méthode de traduction. Montréal: Beauchemin.

Venuti, L. (1998). 'Strategies of Translation'. In M. Baker (ed.). Routledge Encyclopaedia of t Translation Studies. London: Routledge, 240-244. 